\title{
Honor and Humiliation: James Chesnut and Violent Emotions in Reconstruction South Carolina
}

\section{Anna Koivusalo}

University of Helsinki

\begin{abstract}
Reconstruction has been seen as the period of redeeming lost southern honor. I argue, however, that the Reconstruction struggle was not simply about restoring pre-war honor to defeated Southerners, for the Civil War had not terminated or subdued honor. Rather, its contents, the idea of what was honorable, underwent changes. These changes were observed and lamented by James Chesnut, Jr. (1815-1885), a politician from South Carolina. Honor can be seen both as a source of emotion guidelines and as a tool used for navigating between acceptable and unacceptable emotions. By expressing acceptable emotions, an individual could claim ownership to honor and attempt to achieve life goals. During Reconstruction, the role of honor and the importance of honor-related emotional expression intensified. Because of major changes in society, individual goals changed and the necessity of forceful alteration to the understanding of honor arose. It became transformed, borrowing from violence, racism, and a more acute fear of shame. Aiming to preserve white supremacy, many white Southerners readjusted their honor ideals and emotional expression. Nonetheless, some moderate individuals, like Chesnut, found it difficult to adopt these new ideals and thus all but lost their political power.
\end{abstract}

Keywords: Southern honor, history of emotions, James Chesnut, Jr., U.S. Reconstruction, white supremacy

In November 1867, state conservatives gathered in Columbia, South Carolina, to encourage resistance to Congressional Reconstruction and to influence the upcoming elections for a constitutional convention that would decide on equal male suffrage. To that end, this conservative convention issued a public address proclaiming the Reconstruction Acts illegal and clarifying South Carolina's stand on black equality. The conservatives knew, 
they said, that re-establishing slavery was not possible, although it had been the best condition for blacks. "Free negro labor," they explained, was "a disaster, from which (...) it will take years to recover." Even more disastrous, however, was the proposed enfranchisement of the formerly enslaved, who were "utterly unfitted to exercise the highest functions of the citizen." In the name of humanity to both races, the Constitution, the civilization of nineteenth century, and "magnanimity and the noble instincts of manhood," they protested these acts which proposed "not negro equality, merely, but negro supremacy." Such an outcome, the conservatives judged, would insult the honor of white Southerners and humiliate them. ${ }^{1}$

As the mouthpiece of more moderate views, the president of the convention, James Chesnut of Kershaw County, disagreed strongly with this interpretation of southern honor. "I feel it my duty," he said, "to raise my voice in solemn protest against its [the address's] adoption." It would only increase animosity in South Carolina and thus harm all Carolinians, he warned. He begged participants at the conservative convention to carefully weigh their words before submitting the address as such. "I do not regard it as dignified, honorable or proper to appear in the attitude of suppliants, much less to exhibit a spirit of defiance." The address, he stressed, "is to bring upon us additional humiliation, and perhaps profounder contempt." In the war, he argued, Southerners had fought well but had still lost everything save their honor. He was of the opinion that appealing to "these people," by which he meant Northerners, "is to be humiliated." The address, however, was adopted in its original form. ${ }^{2}$

James Chesnut, Jr. (1815-1885) was a politician and a U.S. Senator from Camden, South Carolina. Today he is often dismissed as merely the husband of the brilliant Civil War diarist Mary Boykin Chesnut. However, as a leading figure in the South's secession from the United States in 1861 and as the man who gave the orders to fire the first shots of the American Civil War, his personal contribution to American history is significant. James Chesnut's life choices and actions can be read as responses to the require-

1 "The Conservative State Convention," The Charleston Daily News (Charleston, S.C.), November 9, 1867; “A Conservative Convention," The Camden Journal (Camden, S.C.), November 7, 1867; Richard Zuczek, State of Rebellion: Reconstruction in South Carolina (Columbia, S.C.: University of South Carolina Press, 1996), 40-41.

2 "Protest of General Chesnut" and "Reply of General Chesnut," The Charleston Daily News, November 9, 1867. 
ments of southern honor and connected emotional guidelines. Rather than an unequivocal or static code, however, the prevailing idea of honor was shaped by multiple individual interpretations of honor. Individuals had to constantly recalibrate their notion of honor to coincide with other people's notions of honor. Honor also functioned as a tool for identifying and expressing appropriate emotions.

Chesnut's understanding of honor influenced his actions and politics throughout his life. It also affected how he managed and expressed his emotions as a means of meeting his goals. A reputation as an honorable man was of paramount importance to Chesnut. Until this moment, he had always sought to follow honor's requirements by adapting his actions to the predominant ideal; for example, embracing secession and war after an initial reluctance. ${ }^{3}$ Therefore, the public declaration that Chesnut made at the 1867 conservative convention, strongly disagreeing with his peers, underscores how honor and honorable emotional expression were being transformed in Reconstruction South Carolina.

Most scholars agree that honor's effect on both southern society and on individuals was fundamental. The pioneering work of Bertram WyattBrown, Edward Ayers, and Dickson Bruce at the turn of the 1970s and 1980s has inspired numerous scholars to provide interpretations of southern honor. Although all societies based on honor share similar characteristics, the social structure of the antebellum South-slavery-was so closely intertwined with honor, that, as Bruce, Kenneth Greenberg, and Steven Stowe have shown, the concepts of honor, courage, and masculinity were loaded with connotations different than in other cultures. Honor was seen as applying to the free white men - the planters and the yeomen-who were independent actors in society and in politics. ${ }^{4}$ However, confrontations between

3 For an analysis on how James Chesnut gradually adopted a secessionist stand in politics and then began the war he had previously striven to prevent, see Anna Koivusalo, "He Ordered the First Gun Fired \& He Resigned First': James Chesnut, Southern Honor, and Emotion," in The Field of Honor: Essays on Southern Character \& American Identity, ed. John Mayfield and Todd Hagstette (Columbia, S.C.: University of South Carolina Press, 2017). For more on the interrelationship between southern honor and emotion and James Chesnut's view on both, see Anna Koivusalo, "The Man Who Started the American Civil War: Southern Honor, Emotion, and James Chesnut, Jr.” (Ph.D. diss., University of Helsinki, 2017).

4 Bertram Wyatt-Brown, Southern Honor: Ethics and Behavior in the Old South, 25th anniversary ed. (New York: Oxford University Press, 2007); Bertram Wyatt-Brown, Yankee Saints and Southern Sinners (Baton Rouge: Louisiana State University Press, 1985); Bertram Wyatt-Brown, The Shaping of Southern Culture: Honor, Grace, and War, 1760s-1880s (Chapel Hill: University of North Carolina Press, 2001); Edward L. Ayers, Vengeance and Justice: Crime and Punishment in the 19th-Century American South (New York: 
white men were subconsciously seen as struggles of mastery and subordination. This could also be seen in politics, as Christopher Olsen has argued: honor and manhood were closely linked to politics as the ruling class appealed to both in order to secure its political power. ${ }^{5}$ Twenty-first century scholarship has ventured outside these more traditional views of honor and explored new honor groups or new aspects of honor. ${ }^{6}$

Honor, however, is not uniform and constant. Frank Henderson Stewart, in fact, has argued that it is impossible to have a general theory of honor, since the term "covers a wide variety of concepts, none of which fit together in any clear way."7 Perhaps the best attempt to define honor has been made by Julian Pitt-Rivers, who argued that it consists of honorable behavior, reputation achieved by it, and self-regard based on that reputation. For that reason, it was necessarily performative. ${ }^{8}$ Many scholars stress honor as a code of behavior or a method of control that helped reinforce the social order. Yet, these and other works on honor serve to reaffirm that it had endless manifestations and forms: even scholars who see honor as a code admit that it was not unequivocal.

Oxford University Press, 1984); Dickson D. Bruce, Violence and Culture in the Antebellum South (Austin: University of Texas Press, 1979); Kenneth S. Greenberg, Honor \& Slavery: Lies, Duels, Noses, Masks, Dressing as a Woman, Gifts, Strangers, Humanitarianism, Death, Slave Rebellions, the Proslavery Argument, Baseball, Hunting, and Gambling in the Old South (Princeton, N.J.: Princeton University Press, 1996); Orlando Patterson, Slavery and Social Death: A Comparative Study (Cambridge, Mass.: Harvard University Press, 1982); Steven M. Stowe, Intimacy and Power in the Old South: Ritual in the Lives of the Planters (Baltimore: Johns Hopkins University Press, 1987).

5 Christopher J. Olsen, Political Culture and Secession in Mississippi: Masculinity, Honor, and the Antiparty Tradition, 1830-1860 (New York: Oxford University Press, 2000). Honor, although pronounced in the South, knew no geographic limits in the United States, as Joanne Freeman's work on the influence of honor in the Early Republic period shows. Lorien Foote, too, has argued that honor belonged to Americans both in the North and South during the Civil War and that it had common aspects in both sections. Joanne B. Freeman, Affairs of Honor: National Politics in the New Republic (New Haven: Yale University Press, 2001); Lorien Foote, The Gentlemen and the Roughs: Manhood, Honor, and Violence in the Union Army (New York: New York University Press, 2010).

6 See, e. g., Charity R. Carney, Ministers and Masters: Methodism, Manhood, and Honor in the Old South (Baton Rouge: Louisiana State University Press, 2011); Robert F. Pace and Christopher A. Bjornsen, "Adolescent Honor and College Student Behavior in the Old South," Southern Cultures 6, no. 3 (2000); Robert F. Pace, Halls of Honor: College Men in the Old South (Baton Rouge: Louisiana State University Press, 2004); Robert Elder, "A Twice Sacred Circle: Women, Evangelicalism, and Honor in the Deep South, 1784-1860," Journal of Southern History 78, no. 3 (2012); Bertram Wyatt-Brown, A Warring Nation: Honor, Race, and Humiliation in America and Abroad (Charlottesville: University of Virginia Press, 2014); Mayfield and Hagstette, The Field of Honor.

7 Frank Henderson Stewart, Honor (Chicago: University of Chicago Press, 1994), 21.

8 Julian Pitt-Rivers, "Honor," in International Encyclopedia of the Social Sciences, ed. David Sills (N.p.: MacMillan Free Press, 1968), 503-4. 
I therefore suggest that southern honor, continually developing and being readjusted, was a combination of individual notions of honor-and other related cultural norms. These individual experiences became collective experiences within a particular honor groupa group of people who had a roughly similar idea of what honor was or what it should be. Nonetheless, something that was honorable to one individual was not necessarily so to another, and thus these individual notions also constantly shaped "general" or "public" honor. Further, all of these otherwise outstanding studies almost entirely fail to discuss emotion other than as raw passion that needed to be held in check through honorable behavior. Honor was not, as previous research suggests, merely a method of control. It was more flexible than that: it was a cultural resource that helped an individual to navigate in society. One of its most important tasks was to serve as a guideline for emotional expression. Honor was a tool that enabled Southerners to produce, express, and channel appropriate emotions.

I build my proposition of honor serving as a guideline for emotional management upon classic works on the history of emotions. Emotion historians assume that emotions can be learned and shaped by a culture and that social norms and rules affect individuals' emotional expression. ${ }^{9}$ For example, as Peter and Carol Stearns have concluded, external behavior is not necessarily an expression of an actual emotion but more like an acceptable presentation of an emotion. William Reddy has suggested that emotions are not unchangeable: individuals can learn, manage, and suppress emotions. ${ }^{10}$ Southern society set guidelines for acceptable emotional expressions that helped protect the community structure and individuals were expected to adapt their emotional expression to this ideal. Emotional management in the South was not simply about the suppres-

9 Central works in emotions history include the following: Peter N. Stearns and Carol Z. Stearns, "Emotionology: Clarifying the History of Emotions and Emotional Standards," American Historical Review 90, no. 4 (1985); William M. Reddy, The Navigation of Feeling: A Framework for the History of Emotions (New York: Cambridge University Press, 2001); Barbara H. Rosenwein, "Worrying About Emotions in History," American Historical Review 107, no. 3 (2002); Thomas Dixon, From Passions to Emotions: The Creation of a Secular Psychological Category (Cambridge, UK: Cambridge University Press, 2003); Keith Oatley, Emotions: A Brief History (Malden, MA: Blackwell Pub., 2004); Barbara H. Rosenwein, Emotional Communities in the Early Middle Ages (Ithaca, N.Y.: Cornell University Press, 2006); Ute Frevert, Emotions in History: Lost and Found (Budapest: Central European University Press, 2011); Jonas Liliequist, ed. A History of Emotions, 1200-1800 (London: Pickering \& Chatto, 2012); Susan J. Matt and Peter N. Stearns, eds. Doing Emotions History (Urbana: University of Illinois Press, 2014).

10 Stearns and Stearns, "Emotionology"; Reddy, The Navigation of Feeling, chaps. 3-4. 
sion of emotions, but about attempting to express appropriate, honorable emotions.

By necessity, Southerners reappraised their goals and renegotiated their ideas of honorable behavior by a constant evaluation and recalibration of honor notions. The unstable nature of honor was most obvious in times of crisis, such as during the Civil War and Reconstruction. Then, the role of honor and the importance of honor-related emotional expression intensified. Honor was central to the Redemption movement, the attempt of white Southerners to reclaim their lost political power. I argue that the Reconstruction struggle in the South was not simply about restoring pre-war honor to defeated Southerners, as previous scholarship has argued, because the war did not put an end to or even subdue honor. ${ }^{11}$ Rather, the concept of what was considered honorable behavior and emotional expression changed. Because of major changes in society - the abolition of slavery and the decline of upper-class mastery - individual goals changed and the necessity to forcefully alter the understanding of honor arose. The operations of the $\mathrm{Ku}$ Klux Klan and other violent actions were justified by referring to honor, but the values attached to that notion of honor were, if not totally new, at least distorted versions of it. Honor became transformed, borrowing from violence, racism, and a more acute fear of shame than in the antebellum period. Some emotional expressions, such as hate and anger, which were no longer uncommon, would not have been honorable previously. Meanwhile, notions that had lent force to the pre-war concept of honor held by James Chesnut and many other moderate Southerners, such as self-restraint and chivalry, declined and all but disappeared. Chesnut found it quite difficult to adjust his personal notion of honor to the changing general notion of honor-or the illusion of one general notion of honor.

The South had perhaps lost the war, but its submission to defeat was not, as Michael Perman has noted, "[u]nconditional and passive." Instead, Southerners adopted a "resolute and proud" stand to "resist terms which were considered dishonorable and humiliating." Southerners sought to demonstrate a tactical surrender rather than actually admitting that they had

11 Bertram Wyatt-Brown, e.g., has argued that by the 1880 s, honor was no longer "chastened" by the South's defeat in the war and Reconstruction measures but it was "in the process of being redeemed." WyattBrown, The Shaping of Southern Culture, ch. 12, "Honor Redeemed in Blood." On honor's centrality in resistance to Reconstruction, see, e.g., Lou Falkner Williams, The Great South Carolina Ku Klux Klan Trials, 1871-1872 (Athens: University of Georgia Press, 1996). 
been "whipped." 12 This line of thought can certainly be seen in southern policy. In the fall of 1865, the legislature of South Carolina had embarked upon an endeavor to create so-called black codes, intending to control the emancipated slaves socially and economically and thus make them dependent once again. James Chesnut and other moderates, however, had issued warnings to take northern public opinion into account and use caution. ${ }^{13}$

At the time, James Chesnut had been politically handicapped because of his participation in the Civil War. He had first served as a desk officer and, in the last months of the war, had been on active duty. He had considered military service the duty of all southern men, although he had previously eschewed the use of violence. Chesnut was a peace-loving, calm and moderate man, a thorough gentleman, who believed that honor was required to channel and suppress violence and its expressions. An experienced duel mediator, he had often headed negotiations to resolve disputes concerning violations of honor before the Civil War. He recognized that honor was not only needed to negotiate these procedures, but also to ease individual emotions. He knew how to channel the raw rage, arising from an ill-placed word, to the controlled expression of noble passion in duels.

A U.S. Senator and a Confederate general, Chesnut had not been granted a Presidential pardon after the war, unlike almost all other notable Carolinians. ${ }^{14}$ Therefore, he did not have the right to vote and he participated in politics as a background force: giving speeches, writing letters, and mediating between factions. In the fall of 1865 , Chesnut tried to use his personal influence to persuade the legislature to reject the black codes - while assuring them that he did not disagree so much with the idea behind the codes as with their ill timing. "Unless you want to bring the North down on us," he pleaded, "repeal all laws enacted for negroes and leave the emancipated negro and the white man the same footing before the law." He was right: Congress did not find the southern states behaving as a defeated foe should. ${ }^{15}$

12 Michael Perman, Reunion without Compromise: The South and Reconstruction, 1865-1868 (New York: Cambridge University Press, 1973), 28-29.

13 Zuczek, State of Rebellion, 15-16; Dan T. Carter, When the War Was Over: The Failure of Self-Reconstruction in the South, 1865-1867 (Baton Rouge: Louisiana State University Press, 1985), 63.

14 Andrew Johnson granted pardons liberally to ex-Confederates directly after the war to unite the country. Only a handful of applications from South Carolina were rejected, including that of Chesnut. Perman, Reunion without Compromise, 121-31.

15 "Scrap for the life of James Chesnut," Williams-Chesnut-Manning Collection, South Caroliniana Library, University of South Carolina, Columbia, S.C.; Zuczek, State of Rebellion, 20-21. 
The Republican Congress, without southern representation, wanted equal rights for blacks and southern repentance. Congress fought to force the southern states to accept the Fourteenth Amendment, which would give citizenship rights to the newly freed and thus create a large electorate faithful to the Republican Party. Its ratification was a condition for regaining representation. ${ }^{16}$

In 1867, then, South Carolina's conservative politicians stood in opposition to holding a constitutional convention, as demanded by the Reconstruction bills with the purpose being to ratify the Fourteenth Amendment and provide equal male suffrage. The conservatives attempted first to induce blacks over to the conservatives' side and to control their voting. James Chesnut, worried about the volatile climate in the state, tried in vain to appeal to both white Carolinians and the former slaves - his "colored friends," as he called them. He urged everyone to continue living in peace and cultivate kindly feelings towards one another, as they had done during the fifty years he remembered. The change in the "legal relation" between whites and blacks, he said, should not affect their ability to live as one people with common interests and friendly intercourse. He advised the newly freed to act with moderation and wisdom, to seek information and work hard to support themselves. Chesnut's assertion that he respected their equality and would not take away "one iota" of their rights indicated his desire to restore peace to South Carolina. ${ }^{17}$ Such mild conciliatory rhetoric, however, reflected past ideals that did not serve the needs of Reconstruction-era South Carolina.

In November 1867, as we have seen, Chesnut adamantly opposed the policy of the conservative convention that resisted black equality. Chesnut's concern was not about endorsing black rights; rather, he was repeating other ex-Confederates' cries for manly resistance and not submitting to a former foe. Even though General Robert E. Lee had claimed that surrender before a mightier enemy was not shameful, many Southerners deemed surrender equal to humiliation. Chesnut certainly seemed to think so, for he felt that radical actions would bring them "additional humiliation." His

16 Eric Foner, Reconstruction: America's Unfinished Revolution, 1863-1877 (New York: Harper \& Row, 1988), chap. 5.

17 Perman, Reunion without Compromise, 286; "Public Meeting," The Camden Journal, May 23, 1867; MS, "Remark of Genl Chesnut made on Saturday night May 17, 1867, at a public meeting in Camden," Chesnut-Miller-Manning Papers, South Carolina Historical Society, Charleston, S.C. 
means of appealing to his fellow Carolinians were familiar enough from days past: dignity, honor, and propriety were to be considered. Southern manhood and honor now demanded, however, something other than proper, dignified behavior. The supporters of the address judged black equality and northern rule a humiliation and an insult to their honor, whereas the moderate approach promoted by Chesnut was considered outdated, weak, and even effeminate.

However, the conservatives' plan failed because enough black voters went to the polls, with the result being that a new constitutional convention convened in early 1868 . The convention and the state election results later that year showed that blacks and Republican whites would now dominate South Carolina politics. Under the new Republican government, South Carolina ratified the Fourteenth Amendment and was readmitted to the Union. The power of formerly enslaved, Northern "carpetbaggers," and "scalawags"-native Republican Southerners-horrified and disgusted conservative whites. Some moderates, James Chesnut among them, still hoped that by giving the formerly enslaved "qualified suffrage," they could rule the state along with a few educated and intelligent blacks. ${ }^{18}$ But many other whites disagreed, thinking such a concession disgraceful for the white man's supremacy.

The loss of formal ties to their former slaves made whites search for new ways to control them. The unrepentant Carolinians chose to fight Congressional Reconstruction and the power it gave to former slaves and white Republicans with violent actions, actions which terrorized blacks and left the "carpetbag" government powerless. After the elections, leading conservatives called whites to arms to defend control of their state and white supremacy. Support for the Ku Klux Klan, which had originated in Tennessee as early as 1866, now spread rapidly through South Carolina. The violence that had already been rooted in the state escalated dramatically with the intended aim of controlling and subjugating the emancipated slaves. ${ }^{19}$ Some scholars have seen the Klan as an enforcer of southern honor and other traditional values, such as manhood. Klan members certainly asserted

18 The Anderson Intelligencer (Anderson Court House, S.C.), June 24, 1868; Williams, Ku Klux Klan Trials, 7.

19 Williams, Ku Klux Klan Trials, 1-2 and 16-8; Zuczek, State of Rebellion, 55; W. Scott Poole, Never Surrender: Confederate Memory and Conservatism in the South Carolina Upcountry (Athens: University of Georgia Press, 2004), 109. 
so themselves. Blacks had, they claimed, insulted southern manhood and honor by voting for such a government, which had sought to make blacks equal to the white man. The humiliation was too much to bear. ${ }^{20}$

Although honor was indisputably at the very heart of southern society during Reconstruction, historians have paid little attention to the fact. One of the few scholars to address that question, Adam Fairclough, has argued that the concept of honor changed during Reconstruction so that instead of being a code to resolve personal quarrels, it became a political weapon. Conservative whites attempted to strip white Republicans of their honor by, for example, using such words as "scalawags" to describe them. ${ }^{21}$ I agree that it is obvious that the concept of honor was different in the Reconstruction South than it had been before the Civil War. Nevertheless, I suggest that not only did the way in which honor was used change, but also its content, the notion of what was considered honorable behavior, changed as well.

The elite, wealthy slaveowners, had ruled the South before the war. The loss of that power and emancipation, however, meant that whites of all classes had to negotiate with each other to control the newly freed blacks. The Klan had support in all social classes: men of property were involved as well as members of the lower classes. ${ }^{22}$ Within its operations, then, not only the elite, but all white men, could claim ownership of honor. This also served to change honor, which assumed new meanings via the lower classes, gradually making it more inclusive and collective than it had been before the war. In fact, in speaking of the populist governor Ben Tillman's political victory in 1890, Stephen Kantrowitz has argued that each rival political group in South Carolina "claimed to be defending some concept of 'honor,' but each meaning of honor implied a different kind of masculine prerogative." ${ }^{23}$ Interpretations of honor in the postbellum South, therefore,

20 Foner, Reconstruction, 429; Williams, Ku Klux Klan Trials, 28-31; Wyatt-Brown, Southern Honor, 45458; Wyatt-Brown, The Shaping of Southern Culture, 284-86; Wyatt-Brown, A Warring Nation, chap. 5.

21 Adam Fairclough, "'Scalawags,' Southern Honor, and the Lost Cause: Explaining the Fatal Encounter of James H. Cosgrove and Edward L. Pierson," Journal of Southern History 77, no. 4 (2011), 800-1 and 810.

22 Foner, Reconstruction, 432-33.

23 Charles J. Holden, “'Is Our Love for Wade Hampton Foolishness?': South Carolina and the Lost Cause,” in The Myth of the Lost Cause and Civil War History, edited by Gary W. Gallagher and Alan T. Nolan (Bloomington: Indiana University Press, 2010), 61; Stephen Kantrowitz, "White Supremacist Justice and the Rule of Law: Lynching, Honor, and the State in Ben Tillman's South Carolina," in Men and Violence: Gender, Honor, and Rituals in Modern Europe and America, edited by Pieter Spierenburg (Ohio State University Press, 1998), 216. 
did not just come from the thin upper crust, but from men from very different backgrounds, drawing from such sources as white supremacy, violence, and new views of masculinity.

In the North, the notion of passionate, aggressive manhood-or "masculinity," as it came to be called - replaced the more controlled Victorian manhood in the latter half of the nineteenth century. ${ }^{24}$ Southern men, however, did not embrace northern views of manhood even after the Civil War. In the South, two new forms of manhood, "martial" and "Christian" manhood, emerged instead. The Civil War and post-war violence fueled the ideals of southern martial manhood. While Christian manhood was demonstrated though self-control and self-esteem, its subscribers also believed in violent actions as a means of protecting their dependents and demonstrating their manhood. Honorable behavior was closely connected to these ideals of manhood; such ideals were challenged by the liberation of black men, who were now slightly freer to express their own ideas of manhood. ${ }^{25}$ Manhood ideals, then, further strengthened the idea of violence as honorable.

The ideals of masculinity and honor were enforced by means of lynchings and other forms of ritualistic, performative violence. ${ }^{26}$ Mob law had certainly been unleashed in the South before: what Stephanie McCurry has called "political terror" had helped to advance the Crisis of 1850 and later secession. ${ }^{27}$ Nevertheless, violence during the Reconstruction era, incited by emancipation and military defeat, occurred on a larger scale. At first it was local and uncoordinated. Later, first via the Ku Klux Klan operations and then paramilitary democratic campaigns, violence became more orga-

24 See, e.g., E. Anthony Rotundo, American Manhood: Transformations in Masculinity from the Revolution to the Modern Era (New York: BasicBooks, 1993); Gail Bederman, Manliness \& Civilization: A Cultural History of Gender and Race in the United States, 1880-1917 (Chicago: University of Chicago Press, 1995); Michael S. Kimmel, Manhood in America: A Cultural History (New York: Free Press, 1996); John Pettegrew, Brutes in Suits: Male Sensibility in America, 1890-1920 (Baltimore: Johns Hopkins University Press, 2007). These works concentrate on American masculinity in general, all but excluding its southern variant.

25 Craig Thompson Friend, introduction to Southern Masculinity: Perspectives on Manhood in the South since Reconstruction (Athens: University of Georgia Press, 2009), x-xiii; Joe Creech, "The Price of Eternal Honor: Independent White Christian Manhood in the Late Nineteenth-Century South," in Friend, Southern Masculinity.

26 Kris DuRocher, "Violent Masculinity: Learning Ritual and Performance in Southern Lynchings," in Friend, Southern Masculinity.

27 Stephanie McCurry, Masters of Small Worlds: Yeoman Households, Gender Relations, and the Political Culture of the Antebellum South Carolina Low Country (New York: Oxford University Press, 1995), 292-304, quotation on 296. 
nized, widespread, and generally accepted, as it was seen as helping defend white men and women as a whole. Bertram Wyatt-Brown has argued that lynchings even created a "collective sense of having done a righteous and honorable deed." 28

As a consequence of the change in notions of honor, the emotional values and practices connected to honorable behavior also underwent a transformation during Reconstruction. Barbara Rosenwein has suggested that there are multiple "emotional communities"- groups or people who share the same emotional norms or ideals - within societies rather than one given set of emotion rules. She has proposed that a change in emotional expression occurs when one power group overtakes another and its emotional standards come to the forefront. In a newer study, she has also suggested that emotional communities gain power when "changing circumstances favour their values, goals and expressive repertoires." 29 The significance of emotional communities was pronounced in the South after the Civil War. James Broomall has found that Confederate soldiers, despite coming from different classes, formed the types of emotional communities that Rosenwein describes in her study. Those types of communities continued to exist in the South long after the war had ended in the form of veteran communities, with former soldiers "sharing the legacies and burdens of war and defeat." Later, this helped in the formation of the Ku Klux Klan and similar organizations, which were based on those shared notions of community. Thus, the Civil War changed southern men's understanding of both manhood and emotional expression. ${ }^{30}$

Honor and honorable emotions changed in the Reconstruction South because other whites than the members of the elite gained more power due to social change. However, the contents of honorableness, and consequently honorable emotional expressions, also changed because Southerners' goals altered and became more intensified over time. During Reconstruction, the interests of Southerners underwent a major transformation. Before the Civil War, emotional expressions had been committed to sustaining southern

28 Michael Perman, "Counter Reconstruction: The Role of Violence in Southern Redemption," in The Facts of Reconstruction: Essays in Honor of John Hope Franklin, edited by Eric Anderson and Alfred A. Moss (Baton Rouge: Louisiana State University Press, 1991), 130-32; Ayers, Vengeance and Justice, 268-70; Wyatt-Brown, The Shaping of Southern Culture, 284.

29 Rosenwein, Emotional Communities; Barbara H. Rosenwein, "Theories of Change in the History of Emotions," in Liliequist, A History of Emotions, 1200-1800, 19.

30 James J. Broomall, “'We Are a Band of Brothers': Manhood and Community in Confederate Camps and Beyond," Civil War History 60, no. 3 (2014), 305 and 309. 
community. As the result of a process that had begun during the war, in the Reconstruction South individual views on honor had the objective of benefiting individuals instead of their community. For example, Dolores Janiewski argues that at the end of the century, North Carolinian political leaders used the "vocabulary of fear and anger" to further their own goals. The growing strength of the yeoman and laboring classes, combined with the political issues of the era, resulted in a powerful and passionate emotional climate. Allegations about black men's assaults on white women, for example, were used to excite white voters and intimidate blacks. ${ }^{31}$

The manner in which honorable emotions were expressed changed as well. There had been, of course, violence in the pre-war South, as for example Edward Ayers and Dickson Bruce have shown. The touchiness of a southern man had manifested itself in sporadic fights and duels, when individuals had defended their honor. Honorable emotional expression was the essence of these encounters: controlling one's passions had always separated civilized men from barbarians. The duel, for example, had allowed for public participation in an acknowledged ritual of honor; any outward display of anger during a duel had not been tolerated. ${ }^{32}$ However, mob violence in the Reconstruction South was explicitly emotional. Lynchings in South Carolina were, according to John Hammond Moore, "sudden outbursts of frustration, anger, and fear." Yet, he says, the mobs committing such violence could act in an organized manner, planning their actions. ${ }^{33}$ This shows that such emotions were expressed methodically and were not merely outbursts of passion. Honor still had a role as a tool for managing emotional expression. The changed nature of honor is simply reflected in the claims whites made about the honorableness of violent emotions. While prewar southern society had appreciated such constructive emotions as happiness and cheerfulness, some postbellum emotional expressions were used merely to intimidate others.

The new honor concept was even more closely connected to shame than the pre-war notion. Shame was not, unlike what some scholars ar-

31 Dolores Janiewski, "White Supremacy and the Clash between Passionate and Progressive Emotional Styles in the New South," in Stearns and Lewis, An Emotional History of the United States, quotation on 129.

32 John F. Kasson, Rudeness \& Civility: Manners in Nineteenth-Century Urban America (New York: Hill and Wang, 1990), 157; Bruce, Violence and Culture in the Antebellum South, 6, 19, 65, and passim.

33 John Hammond Moore, Carnival of Blood: Dueling, Lynching, and Murder in South Carolina, 1880-1920 (Columbia: University of South Carolina Press, 2006), 1 and 5. 
gue, merely an emotion; ${ }^{34}$ rather, it was a notion that Southerners sought to avoid via honorable behavior. Such social changes as the Confederate defeat, Yankee rule, and black equality had brought with them so much uncertainty that, to escape the shame of their powerlessness, white men sought to pronounce their honorableness. Pride protects a person's image of himself as honorable and makes him think himself as superior to others. Such a person, however, is necessarily always in danger of losing his position and, thus, being shamed. ${ }^{35}$ The superiority of southern white men, their pride, and their honorableness, had been based on their mastery, manhood, and independence-notions that had now been questioned. The humiliation that northern rule and black equality imposed upon white male Southerners inspired them to engage in brutal extralegal actions, which they defended with claims of pride in their whiteness, mastery, and social order. They wished to avoid shame by humiliating others, in this case non-conservative whites or blacks. ${ }^{36}$ Replacing such gentlemanly, controlled honor scripts as the duel with lynchings, beatings, and burnings demonstrates the fact that honor was not simply being restored, but that its contents, the meaning of honorableness, had radically changed.

In 1871, the federal government tried to end the lawlessness that had almost become a new rebellion in the South. ${ }^{37}$ A Congressional committee was organized to gather information on the Ku Klux Klan. In the Klan hearings, James Chesnut was not charged with associating with the Klan but merely heard as a witness on the conditions in South Carolina. He testified that there indeed was much more crime in the state than before the war, when people were accustomed to self-government. The oppression by "domestic imbeciles and foreign rogues," he insisted, had made the people of South Carolina dissatisfied and rendered "passionate and inconsiderate men violent." Chesnut, who linked honorable behavior with restraint

34 Frank Stewart argues that shame is an emotion, whereas honor is not, and they cannot therefore be opposites. Frank Henderson Stewart, Honor (Chicago: University of Chicago Press, 1994), 129. Unni Wikan questions the tendency of some scholars to see shame simply as the opposite of honor. She argues that whereas honor "is an aspect of the person, shame applies to an act only." Unni Wikan, "Shame and Honour: A Contestable Pair," Man 19, no. 4 (1984), 636.

35 Gabriele Taylor, Pride, Shame, and Guilt: Emotions of Self-Assessment (Oxford: Oxford University Press, 1985), 1; William Ian Miller, Humiliation: And Other Essays on Honor, Social Discomfort, and Violence (Ithaca: Cornell University Press, 1993), 11.

36 Wyatt-Brown, Southern Honor, 436-37.

37 Zuczek, State of Rebellion, 88-89. 
and dignity, found it difficult to respect these new benchmarks for honor. Even though he did not welcome the idea of black equality, he would have liked to live in peace with his black neighbors, many of whom were former slaves of his family. ${ }^{38}$

A member of a prominent family that had built its wealth on cotton and slaves, Chesnut had, as a politician, defended slavery before the war. Yet, according to his wife, he had been a good careless master who treated his slaves kindly and, personally, was not keen to preserve slavery. ${ }^{39}$ After the war, Chesnut's attitude towards the formerly enslaved was, although patronizing, nevertheless lenient for a member of the former ruling class and peculiar to his character. Although many Carolinians were hostile towards black education, Chesnut considered it to be in the interest of and the duty of whites to support it. "If we have to live with them we had better have them educated and good citizens," he explained. Those freedmen who did not respect white authority, however, did not deserve just treatment. The lot of blacks as well as poor whites, Chesnut determined, was, as in antebellum times, to follow "the lead of intelligent gentlemen." Although the legal status of the former slaves was now different, they ought to stay in their subordinate role and look to whites for guidance. Without outside interference, they would have been able to control the blacks, Chesnut explained; in fact, it would have been possible to peacefully return to the status quo ante bellum - white paternalism and black subservience. But now, the old Carolina principle that positioned planters as leaders was being destroyed by "scalawags" and "carpetbaggers." "[A]ll was done that could be done to lash this poor ignorant people into fury against those white people with whom they had to live," Chesnut lamented, disappointed in many freedmen's desertion of their former masters. ${ }^{40}$

Because of the carpetbaggers' influence on the newly freed, Chesnut explained, it had been obligatory for whites to form verbal gentleman associations to preserve order and "suppress incipient riots." The only goal of such associations, he maintained, was to keep the peace. It is unclear whether,

38 U.S. Congress, Testimony Taken by the Joint Select Committee to Inquire into the Condition of Affairs in the Late Insurrectionary States [KKK Hearings], vol. South Carolina I (Washington: Govt. print. off., 1872), 458-70; Williams, Ku Klux Klan Trials, 9.

39 According to Mary Chesnut, James "hates all slavery, especially African slavery." See, e.g., February 25 and March 30, 1865, and August 26, 1861, Mary Boykin Chesnut, Mary Chesnut's Civil War, ed. C. Vann Woodward (New Haven: Yale University Press, 1981), 729, 773, and 163.

40 KKK Hearings, vol. S.C. I, 458-70; Zuczek, State of Rebellion, 31; Poole, Never Surrender, 66-67. 
with these words, Chesnut was only referring to some limited, local organization or whether he was discrediting the significance of the Ku Klux Klan. Most white South Carolinians in the upcountry were in some way, if not part of the organization, then at least aware of its activities ${ }^{41}$ Considering Chesnut's moderate views, it is indeed improbable that he was involved with the organization. Nonetheless, his systematic denial of knowing anything is somewhat unconvincing, if understandable, considering his views on honor. Not wanting to condemn his peers, he showed that he understood, if not the violence, at least the circumstances under which it had originated.

The remedy for these cases of individual violence, Chesnut determined, would be to overthrow the shamelessly corrupt state government and return to a good and honest one. He had no prejudice against honest and intelligent Northerners, merely against bad men who sought their own benefit. Chesnut, as always keen on justice, stressed that he thought that he had kept the terms of his parole, but that the government had not upheld its part of the terms. He, nevertheless, did not intend to violate any laws of the country unless "a state of affairs arises which human nature cannot endure." ${ }^{2}$ Using this kind of terminology from the secession era was no coincidence. In Chesnut's view, human nature could not then and could not now endure such oppression as that which the federal government imposed on Carolinians.

As Congressional Reconstruction efforts increased the stranglehold on South Carolina politics, the Carolinians' discontent became even greater and Chesnut's tones less smooth as well. His words further echoed the secessionist speeches he had given on the eve of the Civil War: he demanded that Carolinians should fight for their lives, liberty, and property and not surrender unconditionally to the "brutal and relentless power" that had op-

41 "Gen. Chesnut's Testimony before the Ku Klux Committee," The Anderson Intelligencer, July 20, 1871; KKK Hearings, vol. S.C. I, 467-68; Williams, Ku Klux Klan Trials, 19-21 and 28; Zuczek, State of Rebellion, 53. Elaine Parsons has argued that the Klan's deliberate secrecy in some matters and its simultaneous, mysterious self-publicizing in others led to Klan skepticism and denial during Reconstruction. Elaine Frantz Parsons, "Klan Skepticism and Denial in Reconstruction-Era Public Discourse," Journal of Southern History 77, no. 1 (2011).

42 "Gen. Chesnut's Testimony before the Ku Klux Committee," The Anderson Intelligencer, July 20, 1871; KKK Hearings, vol. S.C. I, 472. Historians have pointed out that "carpetbag" governments in the Reconstruction South did not consist entirely of white opportunists or ignorant black field hands: many whites were idealists and many blacks were educated freedmen. Nonetheless, most white Carolinians viewed the state government as corrupt and incompetent. Richard Nelson Current, Those Terrible Carpetbaggers (New York: Oxford University Press, 1988); Poole, Never Surrender, 74; Zuczek, State of Rebellion, 136. 
pressed them, their wives, children, and helpless parents. In his opinion, carpetbaggers were "remorseless, insatiate and alien things" who had "no interest, no feeling" in common with Carolinians. The "world's indignation" and "outraged people" would now succeed in overthrowing "the tyranny and stupid misrule," and intelligence, honor, and honesty would triumph. ${ }^{43}$

Despite his colorful depictions of said political oppression, Chesnut always stressed that honor ought not lead to violent and uncontrolled feelings, but instead to noble, controlled expression. Tactics of terror, violence, and intimidation were foreign to Chesnut. Humiliation was not caused by other people's deeds: a person brought it upon himself by dishonorable behavior. Instead of resorting to violence, which he apparently saw as the instrument of people inferior to him, Chesnut sought other remedies for the intolerable political situation. For example, he argued that it was necessary for men of honor to respect the law in regard to other people: "By [honor] I do not mean any fantastic sentiment which might lead to crime," he clarified, "but that sentiment which will (...) compel you, in every case, to respect the rights of others." ${ }^{4}$

Over and over again, Chesnut returned to the idea of honorableness as a means of helping the South return to safer waters. By appealing to it, he believed, it would be possible to direct people's efforts from violence to "all lawful means within our reach" and, at the same time, to encourage all "honest and well meaning citizens," blacks and Republicans alike, to support the cause. "It would be a slander and a stigma upon you to suppose that you will suffer this state of things," he asserted, "so destructive and ignominious, to continue, without exhausting every possible human effort to put an end to it. Your history, your traditions and your personal manhood forbid it." Only those people taking action now would be counted as patriots, "worthy of your ancestry, and true as they to duty and honor." ${ }^{45}$ It was a bold and direct claim in the manner of prior secession speeches, inferring that people who disagreed were in danger of losing their honor and manhood.

43 "Proceedings of the Meeting of the First Instant," The Camden Journal, June 6, 1872; MS, "Fellow Citizens," n.d. [June 1, 1872], Chesnut-Miller-Manning Papers.

44 James Chesnut, An Address Delivered Before the Literary Societies of the College of New Jersey (Princeton: Printed at the "Press" Office, 1876).

45 “An Urgent Appeal to the People of the State," The Kershaw Gazette (Camden, S.C.), July 1, 1874. 
Indeed, Carolinians were jealous of their honor and defended it throughout the Reconstruction years. But Chesnut's goals, remaining faithful to the law and maintaining peace and order, were outdated versions of honor. For honor, as Bertram Wyatt-Brown has argued, expresses itself better through action rather than by cool and rational behavior. ${ }^{46}$ Passivity and moderation, then, are not popular courses of action in volatile times - such as upon the eve of secession or during the Reconstruction era. In the new climate of action and brute force, such men of old-fashioned ideals as Chesnut, "a gentleman of a quiet and philosophical turn of mind," were no longer being listened to. As an acquaintance noted in 1874, Chesnut now belonged to the "old Legion of Honor." ${ }^{47}$ The members of that legion were losing their foothold on the new lines of thought and new views of honor.

The years of Klan resistance were unparalleled in the history of South Carolina in terms of their brutality. The federal government did not succeed in taming the Carolinians' steadfast adherence to white supremacy and their right to self-rule. ${ }^{48}$ The conservatives' campaign against their oppressors went on for eight years. After seeing that sheer intimidation did not work, they set for themselves the task of gradually gaining political control of the state. By 1876, the political tension in South Carolina had coalesced into open resistance against its corrupt government. Wade Hampton III, Chesnut's old friend, became the figurehead of the conservative gubernatorial campaign. Chesnut participated in the campaign, stressing Hampton's manliness and honorableness and the cowardliness of his opponent. Like Chesnut, Hampton was a member of an old, wealthy, prestigious planter family and a relatively moderate conservative. Hampton, however, had the advantage of also being a Confederate soldier-legend, which helped him draw support from men from all classes and lent credence to his paramilitary campaign. While Hampton officially advocated using only a display of military power and "bloodless coercion," many other whites found outright violence to be the clearest expression of white supremacy during and after Hampton's campaign. The carefully planned campaign, its supporting organizations and individual efforts, and the violent methods used by the socalled Red Shirts were effective: Wade Hampton assumed his duties as the

46 Wyatt-Brown, The Shaping of Southern Culture, 32.

47 "Men of High Character," Edgefield Advertiser (Edgefield, S.C.), May 25, 1871; H. C. Stevenson to James Chesnut, June 27, 1874, Williams-Chesnut-Manning Collection.

48 Zuczek, State of Rebellion, 106-8. 
governor of the state in April 1877. This, in effect, ended Reconstruction in South Carolina, the last southern state still subject to it. ${ }^{49}$

Along with Reconstruction, however, Chesnut's political career waned too. After Hampton's election, without a cause to which to dedicate himself, Chesnut sank into political inactivity that was certainly at least partly due to his political disabilities, which were not removed until January $1879 .{ }^{50}$ Although a presidential amnesty proclamation issued in $1867 \mathrm{had}$ returned Chesnut's civil and property rights and allowed him to vote, he, refusing to seek clemency from Congress, had been barred from holding an office. Nonetheless, even after his disabilities were fully removed, Chesnut was not elected to any political posts or appointed to office again. Wade Hampton's success aside, many other members of the "old legion of honor" suffered similar fates. According to Chesnut's gossipy neighbor, one William Johnson, "Chesnuts (...) and such gentlemen will ever [sic] come to the front again, because the people dont [sic] want them." These men could no longer find appointments that would pay enough to cover their expenses and bolster their self-esteem. They, with their old-fashioned honor notions, were now obsolete. ${ }^{51}$

It was not only Chesnut's political career that suffered. The malicious William Johnson also criticized Chesnut's nonexistent role in the famous Cash-Shannon duel.Even though Chesnut had earlier been actively involved in mediating between duelists, by 1880 he was no longer being asked for advice, Johnson explained, "because it was not considered to be of much value." 52 Bertram Wyatt-Brown has argued that Chesnut was reluctant to help because he "belonged to the antebellum past, when such affairs between gentlemen had moral meaning for the participants and onlookers." ${ }^{53}$ It is true that Chesnut saw duels as reflections of the old concept of honor, ill-fitted as it was to postbellum expressions of violence. ${ }^{54}$ James Chesnut

49 "Camden Correspondence," The True Southron (Sumter, S.C.), October 24, 1876; Wade Hampton III to James Chesnut, September 21, 1876, Williams-Chesnut-Manning Collection; Zuczek, State of Rebellion, chap. 8 .

50 U.S. Congress. Senate. 1878. An Act to remove the political disabilities of James Chesnut, of South Carolina. HR 5503. 45th Cong, 3rd sess. (December 13).

51 William E. Johnson to "My Dear Brother," August 25, 1880, Cash-Shannon Duel Collection, South Caroliniana Library; Wyatt-Brown, The Shaping of Southern Culture, 264-65.

52 William E. Johnson to "My Dear Brother," August 25, 1880, Cash-Shannon Duel Collection. For more on the Cash-Shannon duel, see, e.g., Moore, Carnival of Blood, 14-28.

53 Wyatt-Brown, The Shaping of Southern Culture, 271.

54 It is possible that Chesnut's reputation as a mediator and an adviser had also waned because of a personal 
mostly passed his last years in private, at least partly because of his inability to ascribe to postbellum guidelines for honor.

The white supremacist agenda never appealed to Chesnut. He, to be sure, was no supporter of black rights; he deemed the formerly enslaved to both intellectually and socially comprise the lowest caste of society. But his peace-loving nature kept him away from the violent actions taken by the $\mathrm{Ku}$ Klux Klan and the election frauds that many other Southerners regarded as the restoration or redemption of their honor. While he desired to see South Carolina with a powerful upper class, home rule, and white mastery, he wanted it to occur via moderate, conciliatory means. In balancing between loyalty to his peers, many of whom zealously supported white supremacy, and his inclination to protect those dependent upon him, he was, as his habit had always been, trying to tread the middle path. While many ex-Confederates succeeded in politics by flirting with new, violent, active concepts of honor or even openly embracing them, Chesnut hoped to see the old principles of southern honor revived. But these principles had all but been replaced by new, violent declarations of white supremacy, and they were now only remembered in memorial speeches on the "Lost Cause."

\section{Bibliography}

The Anderson Intelligencer (Anderson Court House, SC).

Ayers, Edward L. Vengeance and Justice: Crime and Punishment in the 19th-Century American South. New York: Oxford University Press, 1984.

Bederman, Gail. Manliness \& Civilization: A Cultural History of Gender and Race in the United States, 1880-1917. Chicago: University of Chicago Press, 1995.

Broomall, James J. “'We Are a Band of Brothers': Manhood and Community in Confederate Camps and Beyond." Civil War History 60, no. 3 (2014).

Bruce, Dickson D. Violence and Culture in the Antebellum South. Austin: University of Texas Press, 1979.

The Camden Journal (Camden, SC).

Carney, Charity R. Ministers and Masters: Methodism, Manhood, and Honor in the Old South. Baton Rouge: Louisiana State University Press, 2011.

Carter, Dan T. When the War Was Over: The Failure of Self-Reconstruction in the South, 1865-1867. Baton Rouge: Louisiana State University Press, 1985.

reason. After the war, what may have been depression (or perhaps even post-traumatic stress disorder) caused Chesnut to medicate himself with alcohol often and with increasing doses. Drinking itself was not uncommon: it was a very popular male pastime in the nineteenth-century United States, especially in the South. Wyatt-Brown, Southern Honor, 278. However, in addition to-and probably because of -Chesnut's drinking, his health began to fail quite seriously. During the early 1880 s, he had several strokes that affected his behavior. See Koivusalo, “The Man Who Started the American Civil War," chap. 5. 
Cash-Shannon Duel Collection, South Caroliniana Library, University of South Carolina, Columbia, SC.

The Charleston Daily News (Charleston, SC).

Chesnut, James. "An Address Delivered Before the Literary Societies of the College of New Jersey." Princeton: Printed at the "Press" Office, 1876.

Chesnut-Miller-Manning Papers, South Carolina Historical Society, Charleston, SC.

Creech, Joe. "The Price of Eternal Honor: Independent White Christian Manhood in the Late Nineteenth-Century South.” In Southern Masculinity: Perspectives on Manhood in the South since Reconstruction, edited by Craig Thompson Friend. Athens: University of Georgia Press, 2009.

Current, Richard Nelson. Those Terrible Carpetbaggers. New York: Oxford University Press, 1988.

Dixon, Thomas. From Passions to Emotions: The Creation of a Secular Psychological Category. Cambridge, UK: Cambridge University Press, 2003.

DuRocher, Kris. "Violent Masculinity: Learning Ritual and Performance in Southern Lynchings." In Southern Masculinity: Perspectives on Manhood in the South since Reconstruction, edited by Craig Thompson Friend. Athens: University of Georgia Press, 2009.

Elder, Robert. "A Twice Sacred Circle: Women, Evangelicalism, and Honor in the Deep South, 1784-1860.” Journal of Southern History 78, no. 3 (2012).

Fairclough, Adam. "'Scalawags,' Southern Honor, and the Lost Cause: Explaining the Fatal Encounter of James H. Cosgrove and Edward L. Pierson.” Journal of Southern History 77, no. 4 (2011).

Foner, Eric. Reconstruction: America's Unfinished Revolution, 1863-1877. New York: Harper \& Row, 1988.

Foote, Lorien. The Gentlemen and the Roughs: Manhood, Honor, and Violence in the Union Army. New York: New York University Press, 2010.

Freeman, Joanne B. Affairs of Honor: National Politics in the New Republic. New Haven: Yale University Press, 2001.

Frevert, Ute. Emotions in History: Lost and Found. Budapest: Central European University Press, 2011.

Friend, Craig Thompson, ed. Southern Masculinity: Perspectives on Manhood in the South since Reconstruction. Athens: University of Georgia Press, 2009.

Greenberg, Kenneth S. Honor \& Slavery: Lies, Duels, Noses, Masks, Dressing as a Woman, Gifts, Strangers, Humanitarianism, Death, Slave Rebellions, the Proslavery Argument, Baseball, Hunting, and Gambling in the Old South. Princeton, NJ: Princeton University Press, 1996.

Holden, Charles J. “'Is Our Love for Wade Hampton Foolishness?': South Carolina and the Lost Cause." In The Myth of the Lost Cause and Civil War History, edited by Gary W. Gallagher and Alan T. Nolan. Bloomington: Indiana University Press, 2010.

Janiewski, Dolores. "White Supremacy and the Clash between Passionate and Progressive Emotional Styles in the New South.” In An Emotional History of the United States, edited by Peter N. Stearns and Jan Lewis. New York: New York University Press, 1998.

Kantrowitz, Stephen. "White Supremacist Justice and the Rule of Law: Lynching, Honor, and the State in Ben Tillman's South Carolina." In Men and Violence: Gender, Honor, and Rituals in Modern Europe and America, edited by Pieter Spierenburg. Columbus: Ohio State University Press, 1998.

Kasson, John F. Rudeness \& Civility: Manners in Nineteenth-Century Urban America. New York: Hill and Wang, 1990.

The Kershaw Gazette (Camden, SC). 
Kimmel, Michael S. Manhood in America: A Cultural History. New York: Free Press, 1996. Koivusalo, Anna. "'He Ordered the First Gun Fired \& He Resigned First': James Chesnut, Southern Honor, and Emotion." In The Field of Honor: Essays on Southern Character \& American Identity, edited by John Mayfield and Todd Hagstette. Columbia, SC: University of South Carolina Press, 2017.

Koivusalo, Anna. "The Man Who Started the American Civil War: Southern Honor, Emotion, and James Chesnut, Jr." Ph.D. diss., University of Helsinki, 2017.

Liliequist, Jonas, ed. A History of Emotions, 1200-1800. London: Pickering \& Chatto, 2012.

Matt, Susan J. and Peter N. Stearns, eds. Doing Emotions History. Urbana: University of Illinois Press, 2014.

Mayfield, John, and Todd Hagstette, eds. The Field of Honor: Essays on Southern Character \& American Identity. Columbia, SC: University of South Carolina Press, 2017.

McCurry, Stephanie. Masters of Small Worlds: Yeoman Households, Gender Relations, and the Political Culture of the Antebellum South Carolina Low Country. New York: Oxford University Press, 1995.

Miller, William Ian. Humiliation: And Other Essays on Honor, Social Discomfort, and Violence. Ithaca: Cornell University Press, 1993.

Moore, John Hammond. Carnival of Blood: Dueling, Lynching, and Murder in South Carolina, 1880-1920. Columbia: University of South Carolina Press, 2006.

Oatley, Keith. Emotions: A Brief History. Malden, MA: Blackwell Pub., 2004.

Olsen, Christopher J. Political Culture and Secession in Mississippi: Masculinity, Honor, and the Antiparty Tradition, 1830-1860. New York: Oxford University Press, 2000.

Pace, Robert F. Halls of Honor: College Men in the Old South. Baton Rouge: Louisiana State University Press, 2004.

Pace, Robert F. and Christopher A. Bjornsen, "Adolescent Honor and College Student Behavior in the Old South." Southern Cultures 6, no. 3 (2000).

Parsons, Elaine Frantz. "Klan Skepticism and Denial in Reconstruction-Era Public Discourse." Journal of Southern History 77, no. 1 (2011).

Perman, Michael. Reunion without Compromise: The South and Reconstruction, 18651868. New York: Cambridge University Press, 1973.

Perman, Michael. "Counter Reconstruction: The Role of Violence in Southern Redemption." In The Facts of Reconstruction: Essays in Honor of John Hope Franklin, edited by Eric Anderson and Alfred A. Moss. Baton Rouge: Louisiana State University Press, 1991.

Pettegrew, John. Brutes in Suits: Male Sensibility in America, 1890-1920. Baltimore: Johns Hopkins University Press, 2007.

Poole, W. Scott. Never Surrender: Confederate Memory and Conservatism in the South Carolina Upcountry. Athens: University of Georgia Press, 2004.

Reddy, William M. The Navigation of Feeling: A Framework for the History of Emotions. New York: Cambridge University Press, 2001.

Rosenwein, Barbara H. "Worrying About Emotions in History." American Historical Review 107, no. 3 (2002).

Rosenwein, Barbara H. Emotional Communities in the Early Middle Ages. Ithaca, NY: Cornell University Press, 2006.

Rosenwein, Barbara H. "Theories of Change in the History of Emotions." In A History of Emotions, 1200-1800, edited by Jonas Liliequist. London: Pickering \& Chatto, 2012.

Rotundo, E. Anthony. American Manhood: Transformations in Masculinity from the Revolution to the Modern Era. New York: BasicBooks, 1993.

Stearns, Peter N. and Carol Z. Stearns, "Emotionology: Clarifying the History of Emotions 
and Emotional Standards." American Historical Review 90, no. 4 (1985).

Stewart, Frank Henderson. Honor. Chicago: University of Chicago Press, 1994.

Stowe, Steven M. Intimacy and Power in the Old South: Ritual in the Lives of the Planters. Baltimore: Johns Hopkins University Press, 1987.

Taylor, Gabriele. Pride, Shame, and Guilt: Emotions of Self-Assessment. Oxford: Oxford University Press, 1985.

The True Southron (Sumter, SC).

U.S. Congress. Senate. 1878. An Act to remove the political disabilities of James Chesnut, of South Carolina. HR 5503. 45th Cong, 3rd sess. (December 13).

U.S. Congress. Testimony Taken by the Joint Select Committee to Inquire into the Condition of Affairs in the Late Insurrectionary States [KKK Hearings]. Vol. South Carolina I. Washington: Govt. print. off., 1872.

Wikan, Unni. "Shame and Honour: A Contestable Pair." Man 19, no. 4 (1984).

Williams-Chesnut-Manning Collection, South Caroliniana Library, University of South Carolina, Columbia, SC.

Williams, Lou Falkner. The Great South Carolina Ku Klux Klan Trials, 1871-1872. Athens: University of Georgia Press, 1996.

Wyatt-Brown, Bertram. Southern Honor: Ethics and Behavior in the Old South, 25th anniversary ed. New York: Oxford University Press, 2007.

Wyatt-Brown, Bertram. The Shaping of Southern Culture: Honor, Grace, and War, 1760s1880s. Chapel Hill: University of North Carolina Press, 2001.

Wyatt-Brown, Bertram. A Warring Nation: Honor, Race, and Humiliation in America and Abroad. Charlottesville: University of Virginia Press, 2014.

Zuczek, Richard. State of Rebellion: Reconstruction in South Carolina. Columbia, SC: University of South Carolina Press, 1996. 